\title{
Initial intensive therapy for multibacillary leprosy patients-in retrospect
}

\author{
P S RAO,* B N REDDY, $\dagger$ P KRISHNAMURTHY,* \\ B RAJA RAO, $\$$ M V SASTRULU§ \& A DUTTA* \\ *Central Leprosy Teaching and Research Institute, Chengalpattu \\ 603 001, Tamil Nadu, India, †Regional Leprosy Training and \\ Research Institute, Raipur, Madhya Pradesh, India, $\ddagger N a l g o n d a$, \\ Andhra Pradesh, India and §Srikakulam, Andhra Pradesh, India
}

Accepted for publication 24 March 1992

Summary We analysed the results of 4845 multibacillary (MB) patients being treated with multidrug treatment (MDT) in the Srikakulam District of Andhra Pradesh, India. Of these, $2309(47 \cdot 7 \%)$ patients were given an initial 14-day intensive therapy with rifampicin, clofazimine and dapsone, followed by the WHO recommended pulse therapy. The rest of the cases were given only pulse therapy. The improvement in terms of bacteriological clearance and the proportion of cases declared released from treatment (RFT) was found to be significantly higher among patients treated with only pulse therapy. Clinic attendance was found to be better and more regular in patients treated with intensive therapy, and no relapses were seen with either therapy. The implications of these findings on the operational aspects of programme implementation are discussed.

\section{Introduction}

The WHO study group on chemotherapy for leprosy control programmes recommended multidrug, pulse regimens with rifampicin, clofazimine and dapsone for multibacillary patients and rifampicin and dapsone for paucibacillary patients. ${ }^{1}$ A number of countries where leprosy is endemic incorporated the treatment regimens into their control programmes either exactly as recommended by the WHO or with various modifications. The National Leprosy Eradication Programme in India adopted the WHO recommended regimens but modified the $\mathrm{MB}$ regimen by the addition of a 14-day initial, intensive therapy of rifampicin $(600 \mathrm{mg})$, clofazimine $(100 \mathrm{mg})$ and dapsone $(100 \mathrm{mg})$ daily. ${ }^{2} \mathrm{The}$ modified regimen was advocated only for MB patients who were eligible for MDT on medical screening at the start of the MDT project in an area. Multibacillary patients detected after the start of the MDT project were given direct pulse therapy for operational convenience. Srikakulam District in Andhra Pradesh is one of the districts where the 
MDT project has been implemented since 1983. The purpose of the present analysis is to identify any advantages/disadvantages of the modified regimen compared with the direct pulse therapy.

\section{Materials and methods}

Srikakulam District in Andhra Pradesh was selected for the study because MDT has been used there since 1983 and the maintenance of medical records is good. The study population was $4485 \mathrm{MB}$ patients who started MDT between 1983 and 1988. Of these, $2309(47 \cdot 7 \%)$ patients were given an initial, 14-day supervised, intensive therapy, followed by pulse therapy (IIT Group) and the remaining $2536(52 \cdot 3 \%)$ were treated with direct pulse therapy (DPT Group).

Bacteriologically negative cases were outnumbered at intake, in the DPT group (Figure 1) because certain borderline-tuberculoid (BT) cases, depending on the number of skin and nerve lesions (which changed over time) were given MB MDT, following the National Programme Guidelines. Also a large chunk of MB cases who were on dapsone monotherapy, and became bacteriologically negative in the last 2 years, were required to be given a minimum dose of 24 pulses, as in the programme guidelines, have become DPT group de facto.

As the treatment regimens under study include antibiotics, the bacteriological index (though crude) is considered to be the most important prognostic factor. It also has the advantage of being hard data. The reduction/deterioration in BI and the proportion of cases released from treatment (RFT) were taken as the criteria of response and regularity in treatment and relapses were considered as subsidiary criteria for this study.

The IIT Group was followed-up for 5 years and the DPT Group for 4 years. Hence the analysis is restricted to the initial 4 years only for both groups. Bacteriological positivity was recorded using Dharmendra's method. Patients put on either of the regimens were declared as RFT when they became clinically inactive and bacteriologically negative or had received 24 pulses in 36 months, whichever was later.

\section{Results}

INITIAL BACTERIOLOGICAL PROFILE

Figure 1 shows the bacteriological profile of the patients in the IIT and DPT groups at the commencement of MDT. The 2 groups are significantly different and if analysed for the groups as a whole the differences may mask the beneficial effects of IIT. To avoid this and to make comparison possible, the analysis was done for each group separately.

\section{RFT RATE}

The multiple bar diagram (Figure 2) shows that a significantly higher proportion of cases were RFT from the DPT group when compared with the IIT group. This difference is consistently seen after the $24 \mathrm{th}, 36 \mathrm{th}$ and $48 \mathrm{th}$ pulses. However, the high percentage of bacteriologically-negative patients at intake in the DPT group might have resulted in a better RFT rate at the 24 th pulse. 

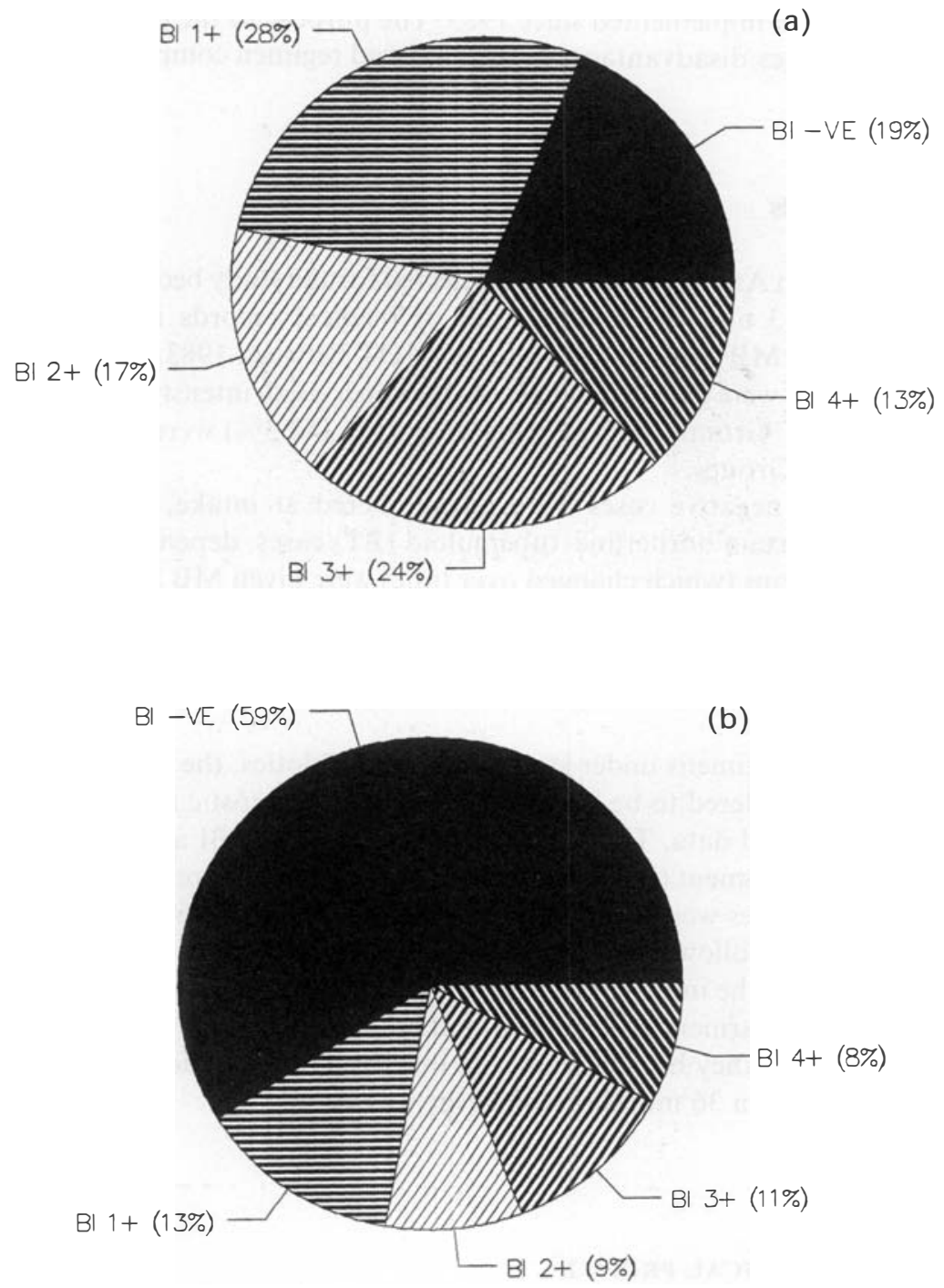

Figure 1. Bacteriological profile at intake: (a) IIT (2125); and (b) DPT (2347).

\section{BACTERIOLOGICAL POSITIVITY}

Tables 1,2 and 3 show the bacteriological positivity in patients to be positive at the start of treatment and at the 24th, 36th and 48th pulses. The percentage of cases remaining bacteriologically positive was found to be directly proportional to the initial BI and was inversely proportional to the duration of the treatment. In this respect, in both the IIT and DPT groups, the response is comparable, but the actual figures were consistently and significantly lower for the patients belonging to DPT group. 

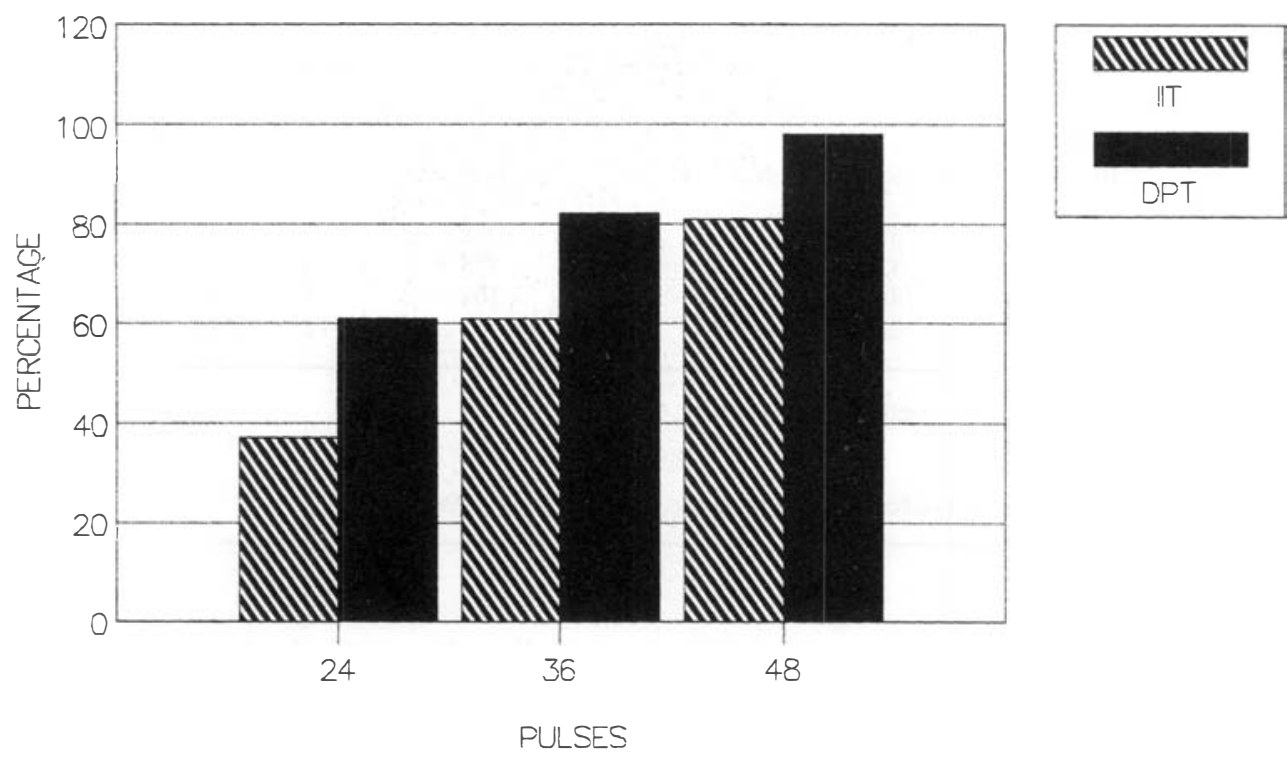

Figure 2. Proportion of cases released from treatment.

Table 1. Bacteriological positivity after the 24 th pulse

\begin{tabular}{|c|c|c|c|c|c|c|}
\hline \multirow{2}{*}{$\begin{array}{l}\text { Initial } \\
\text { BI }\end{array}$} & \multicolumn{3}{|c|}{ IIT } & \multicolumn{3}{|c|}{ DPT } \\
\hline & No. examined & No. + ve & $\%$ & No. examined & No. + ve & $\%$ \\
\hline$>0-\leqslant 1+$ & 579 & 197 & $34 \cdot 0$ & 305 & 52 & $17 \cdot 0$ \\
\hline$>1-\leqslant 2+$ & 345 & 225 & $65 \cdot 2$ & 197 & 102 & $51 \cdot 8$ \\
\hline$>2-\leqslant 3+$ & 494 & 432 & $87 \cdot 4$ & 240 & 186 & $77 \cdot 5$ \\
\hline$>3-\leqslant 4+$ & 263 & 251 & $95 \cdot 4$ & 166 & 150 & $90 \cdot 3$ \\
\hline
\end{tabular}

$$
(P<0 \cdot 05 .)
$$

Table 2. Bacteriological positivity after the 36 th pulse

\begin{tabular}{|c|c|c|c|c|c|c|}
\hline \multirow{2}{*}{$\begin{array}{l}\text { Initial } \\
\text { BI }\end{array}$} & \multicolumn{3}{|c|}{ IIT } & \multicolumn{3}{|c|}{ DPT } \\
\hline & No. examined & No. + ve & $\%$ & No. examined & No. + ve & $\%$ \\
\hline$>0-\leqslant 1+$ & 577 & 67 & $11 \cdot 6$ & 262 & 11 & $4 \cdot 2$ \\
\hline$>1-\leqslant 2+$ & 338 & 83 & $24 \cdot 6$ & 149 & 28 & $18 \cdot 8$ \\
\hline$>2-\leqslant 3+$ & 488 & 287 & $58 \cdot 8$ & 160 & 65 & $40 \cdot 6$ \\
\hline$>3-\leqslant 4+$ & 241 & 179 & $74 \cdot 3$ & 104 & 65 & $62 \cdot 5$ \\
\hline
\end{tabular}

$(P<0.05$ for all groups except for $2+$. 
Table 3. Bacteriological positivity af ter the 48 th pulse

\begin{tabular}{|c|c|c|c|c|c|c|}
\hline \multirow{2}{*}{$\begin{array}{l}\text { Initial } \\
\text { BI }\end{array}$} & \multicolumn{3}{|c|}{ IIT } & \multicolumn{3}{|c|}{ DPT } \\
\hline & No. examined & No. + ve & $\%$ & No. examined & No. + ve & $\%$ \\
\hline$>0-\leqslant 1+$ & 571 & 16 & $2 \cdot 8$ & 238 & 1 & $0 \cdot 4$ \\
\hline$>1-\leqslant 2+$ & 338 & 27 & $8 \cdot 0$ & 125 & 0 & $0 \cdot 0$ \\
\hline$>2-\leqslant 3+$ & 458 & 105 & $22 \cdot 9$ & 101 & 4 & $4 \cdot 0$ \\
\hline$>3-\leqslant 4+$ & 223 & 96 & $43 \cdot 0$ & 52 & 12 & $23 \cdot 0$ \\
\hline
\end{tabular}

$(P<0.05$ excepting $2+$ Group. $)$

Table 4. Bacteriological progress after the 24 th pulse

\begin{tabular}{|c|c|c|c|c|c|c|}
\hline & \multicolumn{3}{|c|}{ IIT } & \multicolumn{3}{|c|}{ DPT } \\
\hline & No. & No. examined & $\%$ & No. & No. examined & $\%$ \\
\hline Improved* & 1278 & 1681 & $76 \cdot 0$ & 764 & 908 & $84 \cdot 1$ \\
\hline Static & 745 & 2080 & $35 \cdot 0$ & 1499 & 2293 & $65 \cdot 3$ \\
\hline Worsened $\dagger$ & 57 & 1817 & $3 \cdot 1$ & 30 & 2127 & $1 \cdot 4$ \\
\hline
\end{tabular}

* Initial B I negative cases are excluded from both the groups as improvement beyond negativity cannot be measured.

$\dagger$ Initial BI 4 plus cases are excluded from both the groups as BI worsening beyond 4 plus cannot be measured under Dharmendra's method $(P<0.001)$.

Table 5. Bacteriological worsening under two regimens

\begin{tabular}{lccc}
\hline Pulse & $\begin{array}{c}\text { No. showing } \\
\text { worsening }\end{array}$ & $\begin{array}{c}\text { No. } \\
\text { examined }\end{array}$ & $\%$ \\
\hline 24th & & 1817 & $3 \cdot 1$ \\
IIT & 57 & 2127 & $1 \cdot 4$ \\
DPT & 30 & & \\
36th & & 1801 & $0 \cdot 49$ \\
IIT & 9 & 1831 & $0 \cdot 27$ \\
DPT & 5 & & \\
48th & & 1766 & $0 \cdot 11$ \\
IIT & 2 & 1698 & $0 \cdot 00$ \\
DPT & 0 & & \\
\hline
\end{tabular}

Differences are statistically significant at the 24 th Pulse only $(P<0.001)$.

\section{BACTERIOLOGICAL PROGRESS}

Bacteriological progress made by these 2 groups as assessed at the end of 24th pulse are given in Table 4. Overall progress made was significantly better for DPT group. Similar 
analysis at the 36th and 48th pulse could not be undertaken due to logistic problems and the non-availability of data. However, bacteriological deterioration alone was studied at the 36 th and 48 th pulses and the results (Table 5) show that deterioration is comparable in both groups.

\section{CLINIC ATTENDANCE}

At the end of the 36 th month, only $1 \cdot 2 \%$ of the cases had not completed the required 24 pulses in the IIT group and $16.5 \%$ had not completed in the DPT group.

\section{RELAPSES}

No relapses were reported in either group during the periods they were under surveillance following RFT.

\section{Discussion}

From the analytical results, it appears that the only advantage of the initial 14-day supervised therapy when compared with direct pulse therapy is the regularity of treatment compliance. Even this might be due to the fact that the majority of IIT group patients were under dapsone monotherapy and the change of therapy to better drugs and the initial enthusiasm of the MDT project implementation might have motivated them to be regular attenders. On the other hand, the DPT group showed better results in terms of BI reduction at the 24 th pulse, the proportion of RFT, BI deterioration and comparable results with regard to relapses. The better response of the group without intensive therapy has been reported by others. ${ }^{3,4}$ It is also reported that a regimen consisting of daily, initial administration of rifampicin for 21 days did not show distinct advantages over the WHO regimen. $^{5}$

Rifampicin kills Mycobacterium leprae with exceptional speed-99\% a few days after a single dose of $600 \mathrm{mg}$ or $1500 \mathrm{mg} .{ }^{6}$ It has been shown that daily administration of $600 \mathrm{mg}$ of rifampicin is no more effective than monthly administration of $600 \mathrm{mg}$ on each of 2 consecutive days. ${ }^{7}$ Studies proved that with both $600 \mathrm{mg}$ daily rif ampicin and $600 \mathrm{mg}$ as a single dose, the proportion of infective organisms fell to undetectable levels within 1 or 2 weeks after initiating treatment. ${ }^{8,9}$ There is no experimental evidence in support of the 14day initial intensive therapy. Perhaps it is based on the theroretical assumption that the generation time of $M$. leprae is about 14 days, and therefore coverage of the entire generation time by a powerful bactericidal drug, namely rifampicin, will kill most of the organisms, thereby causing source reduction and a decline in the spread of infection. This needs to be substantiated by controlled studies.

However, the implementation of 14-day initial supervised therapy is operationally cumbersome and financially burdensome-costing about Rs. 100,000 for an average leprosy control unit with a prevalence rate of 10 per 1000 , including the cost of drugs, petrol, oil and lubricants, travelling allowance/daily allowance for staff, etc. It is also time consuming since it would take 8 months to 1 year to complete the intensive therapy in a given leprosy control unit and ethically questionable because it exposes the patients to the added risk of the toxic side-effects of rifampicin. It is of ten argued that by visiting the 
villages daily for 14 days, the medical teams will help to build the confidence of the patients and have a positive impact on new case detection, community education and participation. This may be true to some extent. Again, these arguments need to be confirmed by further studies. Even if the above arguments were true, the same result could probably be achieved by a 14-day, intensive, health education campaign in the treatment circuits. This would save the patients from exposure to the possible toxic side-effects of an additional 13 pulses of rifampicin and also reduce the exhorbitant cost of the drugs.

\section{Recommendations}

Since many districts have completed their intensive phase of NLEP in the country, it is suggested that:

(i) data be collected and analysed so that a reasonable conclusion on the value of 14-day initial intensive therapy can be reached; so, also, data from control programmes may be collected and analysed in other countries, where initial intensive therapy is in vogue; and

(ii) since the WHO recommended MDT regimens are being implemented unmodified in some other countries, the experiences of those countries might help us in reviewing the necessity for initial, intensive therapy for MB cases.

\section{Acknowledgments}

We would like to extend our grateful thanks to Dr G V N Rao, Director of Public Health, Andhra Pradesh for giving us permission to use the field data and to Dr B K Rao, NLEP Consultant, Andhra Pradesh in facilitating our work. The thorough collection and tabulation of data by the paramedical staff, especially, Shri Madhava Rao, Non-Medical Supervisor of District Leprosy Office, Srikakulam are also gratefully acknowledged. Lastly, we would like to extend our thanks to Shri P Sirumban, Senior Statistical Assistant, Shri M Subramanian, Statistical Assistant and Shri S Ganesa Narasimman, Stenographer for their assistance in data processing and secretarial work, respectively.

\section{References}

1 WHO Study Group, Chemotherapy of Leprosy for Control Programmes, Technical Report Series No. 675, WHO, Geneva, 1982; 21-6.

2 Guidelines for Multidrug Treatment in endemic districts, National Leprosy Eradication Programme, Directorate General of Health and Family Welfare, Nirman Bhawan, New Delhi, 1989; 9.

${ }^{3}$ Rangan Sheela G, Kothari Gopa A, Gandrwan KL, Ganapathi R. MDT in MB leprosy cases in urban control. A study in Bombay. Ind J Lepr, 1989; 61: 190-5.

4 Chopra NK, Agarwal JS, Pandian PH. Impact of MDT in leprosy in Baroda District (Gujarat). Ind J Lepr, 1989; 61: 179-89.

${ }^{5}$ Ganapathi R, Revankar CR, Rashmi R Pai. Three years assessment of multidrug therapy in multibacillary leprosy cases. Ind J Lepr, 1987; 59: 44-9.

6 WHO Expert Committee on leprosy, VI Report, Technical Report Series No 768, WHO, Geneva, $1988 ; 29$.

7 WHO. A Guide to Leprosy Control. 2nd Edition. WHO, Geneva, 1988; 33. 
8 Levy L, Shepard G.C. Fasal P. The bactericidal effect of rifampicin in (a) single dose of 600, 900 and $1200 \mathrm{mg}$ and (b) daily doses of $300 \mathrm{mg}$. Int $J$ Lepr, 1976; 44: 183-7.

9 Grosset GH. Recent developments in the field of multidrug therapy and future research in Chemotherapy of leprosy. Lepr Rev 1986; 57, suppl. 3, 223-34.

Lepr Rev (1992) 63, 350-357

\title{
Thérapeutique d'attaque intensive chez les patients lépreux multibacillaires- étude rétrospective
}

\author{
P S Rào, B N Reddy, P Krishnamurthy, B Raja Rau, M S Sastrulu et
} A Dutta

Résumé Nous avons analysé les résultats obtenus chez 4845 patients multibacillaires (MB) en cours de traitement multidrogue (MDT) dans un district Srikakulam de Andhra Pradesh, Inde. Parmi ceux-ci, 2309 $(47,7 \%)$ ont reçu une thérapeutique d'attaque intensive de 14 jours de rifampicine, clofazimine et dapsone, suivie de la thérapeutique intermittente recommandée par WHO. Les autres cas ont reçu seulement la thérapeutique intermittente. L'amélioration, exprimée par la clearance bactérienne et la proportion des cas déclarés comme libérés de traitement (RFT), s'est révélée significativement plus élévée chez les patients traités seulement par la thérapeutique intermittentee. Les patients traités par la thérapeutique d'attaque étaient plus assidus et réguliers dans leurs visites à la clinique, et aucune rechute n'a été observée avec les deux thérapeutiques. Les implications de ces observations sur les aspects opérationnels du programme sont discutées.

\section{Terapia intensa inicial para los pacientes leprosos multibacilares-en retrospectiva}

\author{
P S Rao, B N Reddy, P Krishnamurthy, B Raja Rau, M S Sastrulu y \\ A Dutta
}

Resumen Análizamos los resultados de 4.845 pacientes multibacilares (MB) que recibían tratamiento multidroga (TMD), en el Distrito de Srikakulam de Andra Pradesh, India. 2309 (47,7\%) pacientes recibieron una terapia inicial intensa con rifampicina, cloazimina y dapsona, seguidos por la terapia por pulsación recomendada por la OMS. Los demás casos solamente recibieron solamente la terapia por pulsación. La mejora expresada como aclaramiento bacteriológico y la proporción de casos declarados librados de tratamiento era significativamente más alta en los pacientes tratados solamente con la terapia por pulsación. Asistencia a las clínicas era mejor y más regular en el caso de los pacientes tratados por terapia intensa, y no se observaron relapsos con cualquier terapia. Se discuten las implicaciones de estos resultados sobre los aspectos operativos del programa. 